\title{
Acute Administration of Nymphaea lotus Increases Body Weight and Exploratory Behaviour in Mice
}

\author{
Aduema Wadioni ${ }^{1}, *$, Vidona WB ${ }^{2}$, Akunneh-Wariso Chris ${ }^{3}$, Amah Akuma Kalu ${ }^{4}$
}

\section{Aduema Wadioni ${ }^{1, *}$, Vidona WB', Akunneh-Wariso Chris ${ }^{3}$, Amah Akuma Kalu ${ }^{4}$}

\begin{abstract}
'Department of Human Physiology, PAMO, University of Medical Sciences, Port Harcourt, Rivers State, NIGERIA. ${ }^{2}$ Department of Human Anatomy, Edo State University, Iyamo, NIGERIA. ${ }^{3}$ Department of Human Physiology, Abia State University, Uturu, NIGERIA. ${ }^{4}$ Department of Human Physiology, Imo State University, Imo State, NIGERIA.
\end{abstract}

\section{Correspondence}

\section{Dr. Aduema Wadioni}

Department of Human Physiology, PAMO University of Medical Sciences, Port Harcourt, Rivers State, NIGERIA.

Phone: +23408038046678

Email: wadioniaduema@gmail.com

\section{History}

- Submission Date: 03-07-2019;

- Review completed: 13-08-2019.

- Accepted Date: 30-08-2019.

DOI : 10.5530/ijcep.2019.6.3.23

\section{Copyright}

(c) 2019 Phcog.Net. This is an openaccess article distributed under the terms of the Creative Commons Attribution 4.0 International license.

\begin{abstract}
Background and Aim: The effects on body weight and exploratory behavior following acute administration of the leaves of Nymphaea lotus were determined using mice as experimental animals. Methods: Thirty Swiss white mice were randomly divided into group A, B and C. All the mice had access to clean drinking water ad libitum. Before the neurobehavioral parameters were assessed, the $L_{50}$ and the phytochemical screening of the leaves of the plant were determined. The open field maze and the light/dark transition box apparatus were used to determine the level of exploratory behaviors in mice. Results: In the open field maze, the line crosses and rearing frequency were significantly different when compared to control $(P<0.01)$. Stretch Attend Posture frequency (SAP) was significantly higher in the test groups when compared to control $(P<0.01)$. It was also observed that the frequency of grooming in the light/dark transition box decreased in the treated groups when compared to the control group $(P<0.05$ and at $P<0.01)$. Frequency of transition were significantly higher $(P<0.01$ and at $P<0.001)$ compared to control. The body weight was significantly higher in the mice treated groups when compared to control $(P<0.01)$. Conclusion: Thus, the leaves of Nymphaea lotus enhances exploratory behavior and increases body weight in mice. Key words: Exploratory behaviors, Body weight, Open field maze, Light/dark box, Nymphaea lotus, Mice.
\end{abstract}

\section{INTRODUCTION}

Plants or herbs which are used for traditional medicine contain a wide range of substances that can be used to treat chronic and infectious diseases, including neurological disorders. ${ }^{[1]}$ Many of today's synthetic drugs originated from the plant kingdom. Herbal medicine went into rapid decline when basic and clinical pharmacology established themselves as leading branches of medicine. Nevertheless, herbal medicine is still of interest in many diseases, in particular, neurological disorders. ${ }^{[2]}$ Nymphaea lotus (water lily) belongs to Nymphaeaceae family. It is a perennial plant that grows up to $45 \mathrm{~cm}$ in height; it is an herbaceous aquatic plant, whose leaves floats or submerges in water. ${ }^{[3]}$ This plant is localized to Central and Southern Europe, Asia, the Middle East, North Africa, tropical mountains in Africa and West Africa especially in Nigeria. Many bioactive and pharmacologically important compounds have been obtained from the plant and used in medicine and pharmacy. ${ }^{[4,5]}$

The leaves of Nymphaea lotus were tested for antibacterial activity against some bacteria isolated from wounds, since it is being used in traditional medicine. The plant contains a number of bioactive phytochemical constituents and produces a calming and sedative effect on the nervous system, suggesting that the plant can therefore be used in treatment of disorders such as insomnia, anxiety and other related disorders. ${ }^{[6]}$ Therefore the aim of the study was to investigate the effect of the plant exact on exploratory behavior and body weight using mice as the experimental animal Disorders of locomotion/ exploration are neurological syndromes which are common among humans. However, modern synthesized drugs for these disorders are costly and not always readily available for people in the rural areas. Therefore, it is important to carry out this study in order to provide solution to this problem using plant which will be more affordable with fewer side effects; hence, this study will go a long way in solving this problem.

\section{MATERIALS AND METHODS}

\section{Animal Care}

Thirty (30) Swiss white mice having a body weight between 19-24 g were used in study. The animals were kept in the animal house of the Department of Physiology, Ututru, Abia State, Nigeria. The animals were kept in a hygienic and well-ventilated environment and maintained under standard environmental conditions. Animals were fed with normal rat chow

Cite this article: Wadioni A, Vidona WB, Chris A, Kalu AA. Acute Administration of Nymphaea lotus Increases Body Weight and Exploratory Behaviour in Mice. Int J Clin Exp Physiol. 2019;6(3):82-5 
and allowed water ad libitum for 21 days for acclimatization of the animals.

\section{Experimental Design}

Thirty (30) Swiss mice were randomly divided into three groups A, B and $\mathrm{C}$ of 10 mice per group. Group A was the control; groups B and C were for the treated groups respectively. Animals in group A received normal rat chow; group B animals received $15 \mathrm{mg} / \mathrm{kg}$ and group C, received $30 \mathrm{mg} /$ $\mathrm{kg}$ of the plant extract daily for a period of 21 days.

\section{Experimental Procedures}

A). Open field test: Each mice was scooped up with a plastic container and then placed in the open field arena and allowed to explore the apparatus for $5 \mathrm{~min}$ and certain behaviors scores were taken into consideration, which are, line crosses, center square duration, rearing frequency and grooming, etc.

\section{B) Light/dark transition box}

1. Each mouse was picked by the base of its tail and placed in the centre of the white compartment facing the door to the dark compartment and allowed to explore the apparatus for five minutes.

2. The mice behaviors were scored within the period and the maze was cleaned with alcohol between tests and then allowed to dry.

Behaviors scored included: Transition, stretch attends posture and grooming.

\section{Statistical Analysis of Data}

Data Obtained from the experiments were statistically analysised using Microsoft excel, with factorial ANOVA/t-test in the statistics programme start view version for windows or Mac. Post-hoc comparison was also done using the student \pm Newman-keuls design. Values were represented as Mean \pm SEM and a " $P$ " value less than 0.05 , was considered as significant.

\section{RESULTS}

\section{Open Field Maze}

Line crosses (Figure 1)

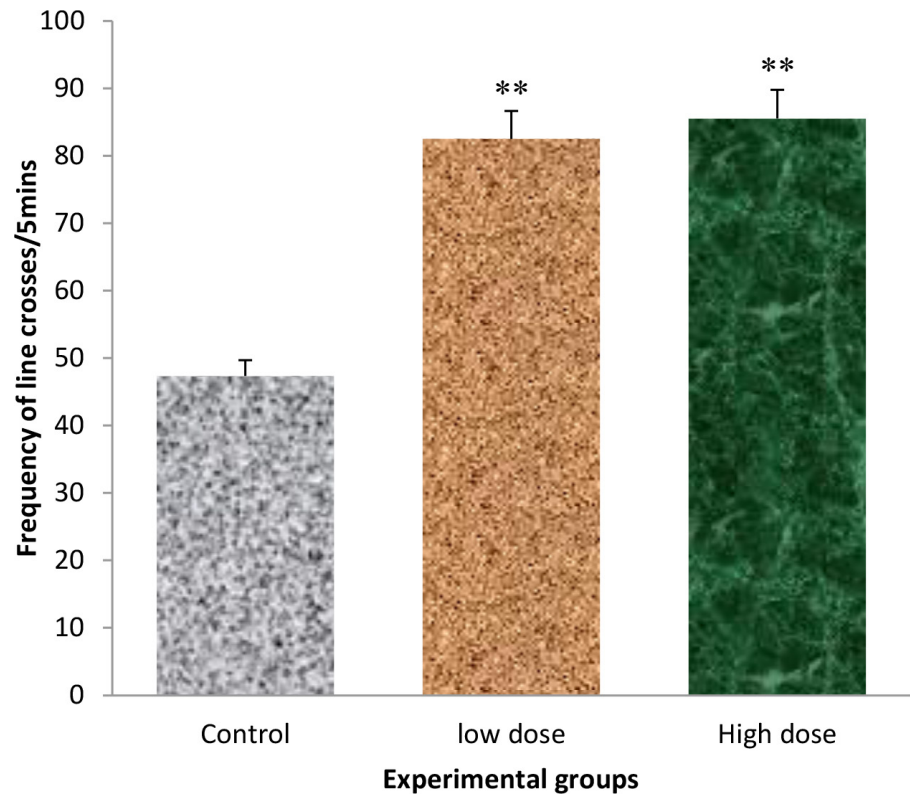

Figure 1: Comparison of line crosses in the open field maze test, in the control and Nymphaea lotus treated groups. Values are mean $\pm \mathrm{SEM}, n=10$. ${ }^{*} P<0.01$ vs. control.
The mean values for the control and test groups(low and high dose) were, $47.32 \pm 7.26 / 5 \mathrm{mins} ; 82.50 \pm 5.62 / 5 \mathrm{mins}$ and $85.49 \pm 1.61 / 5 \mathrm{mins}$. The frequency of line crosses of the low and high dose group of mice were significantly higher $(P<0.01)$ compared to control.

Rearing frequency (Figure 2)

The frequency of rearing for the control and test group (low and high dose) treated mice were significantly different compared to the control $(P<0.01)$. Their mean values were, $13.0 \pm 8.82 / 5 \mathrm{mins} ; 7.0 \pm 2.32 / 5 \mathrm{mins}$ and $11.5 \pm 1.59 / 5 \mathrm{mins}$.

Stretch attend posture (Figure 3)

Their mean values for the control and test groups were, $3.20 \pm 0.5 ; 1.50 \pm 0.36 / 5 \mathrm{mins}$ and $2.83 \pm 0.10 / 5 \mathrm{mins}$. The frequency of stretch attend posture in the low and high dose group treated with Nymphaea lotus were significantly lower $(P<0.01)$ compared to control.

\section{Light/Dark Transition Box}

Frequency of transition (Figure 4)

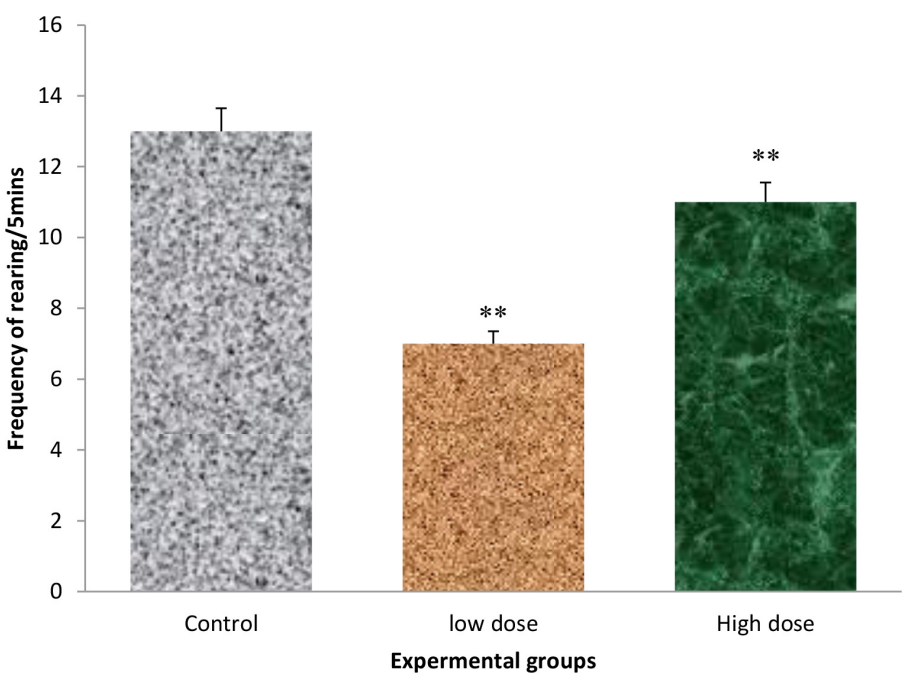

Figure 2: Comparison of rearing frequency in the open field test, in the control and Nymphaea lotus treated groups. Values are mean \pm SEM, $n=10$. ${ }^{*} P<0.01$ vs. control.

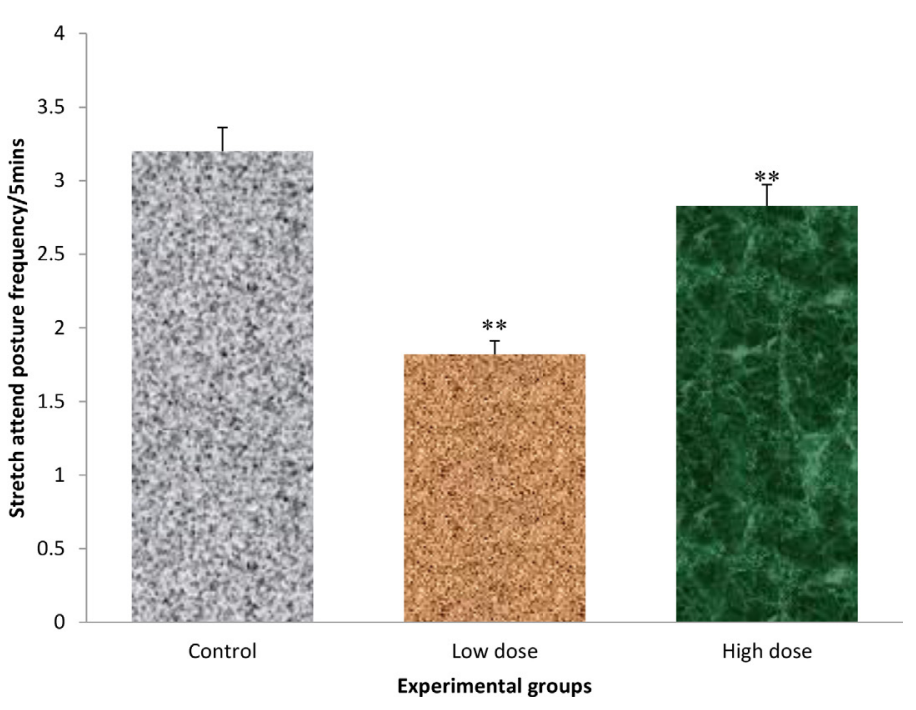

Figure 3: Comparison of Stretch attends posture in the open field maze test, in the control and Nymphaea lotus treated groups. Values are mean $\pm \mathrm{SEM}$, $n=10$. ${ }^{*} P<0.01$ vs. control. 
The mean values for the control and the Nymphaea lotus treated group were, $12.21 \pm 1.96 / 5 \mathrm{mins} ; 18.26 \pm 1.50 / 5 \mathrm{mins}$ and $21.54 \pm 0.62 / 5 \mathrm{mins}$. The mice treated with low and high dose of Nymphaea lotus were significantly different compared to the control $(P<0.01$ and at $P<0.001)$.

\section{Grooming frequency (Figure 5)}

The mean values for the control and the Nymphaea lotus treated group were, $2.32 \pm 0.33 / 5 \mathrm{mins} ; 1.22 \pm 0.23 / 5 \mathrm{mins}$ and $1.12 \pm 0.10 / 5 \mathrm{mins}$. The mice treated with low and high dose of Nymphaea lotus were significantly different compared to the control $(P<0.05$ and at $P<0.01)$.

Body weight change (Figure 6)

The mean values were $73.03 \pm 7.0 \mathrm{~g}$ for control and $124 \pm .12 .8 \mathrm{~g}$ and $126 \pm .11 .1 \mathrm{~g}$ for the low and high dose group. The low and high dose

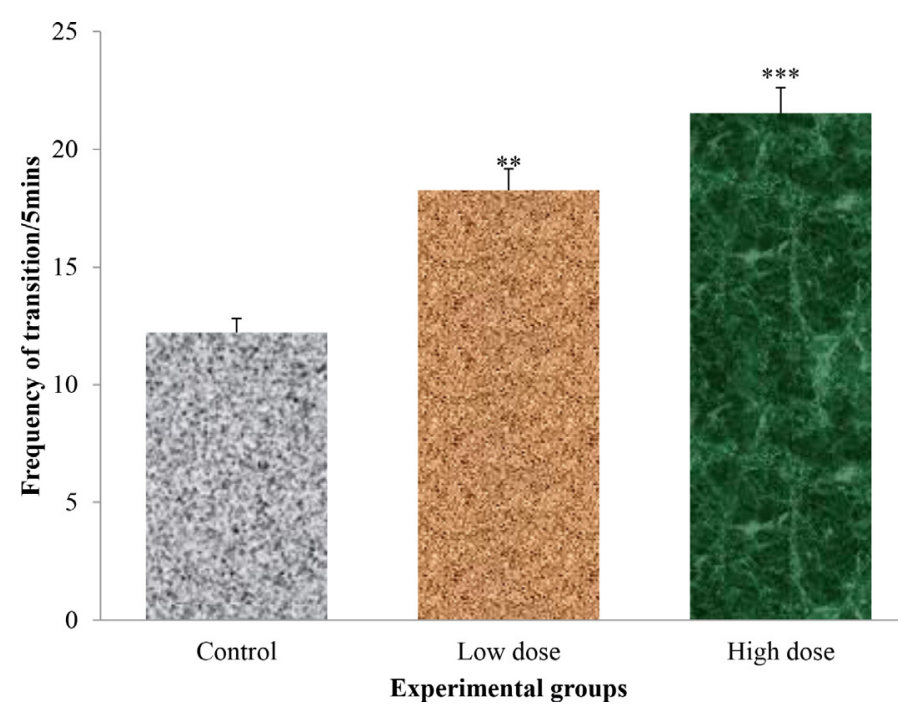

Figure 4: Comparison of the frequency of transition in the light-dark box test, in the control and Nymphaea lotus treated groups. Values are mean \pm SEM, $n=10$.

${ }^{*} P<0.01$ vs. control,

${ }^{* * *} P<0.001$ vs. control.

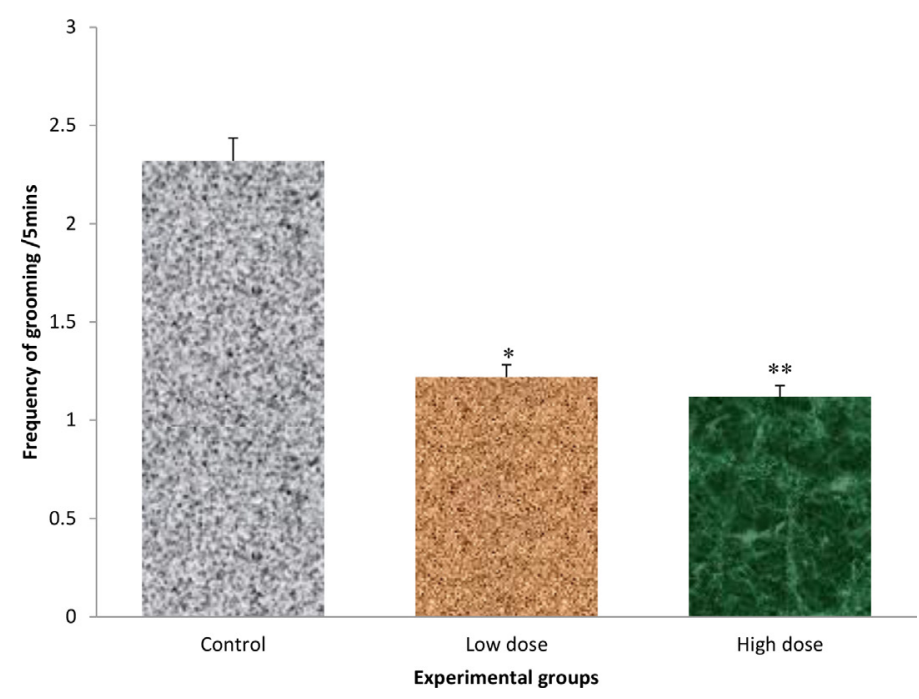

Figure 5: Comparison of the frequency of grooming in the light-dark box test, in the control and Nymphaea lotus treated groups. Values are mean \pm SEM, $n=10$.

${ }^{*} P<0.05$ vs. control,

${ }^{*} P<0.01$ vs. control.

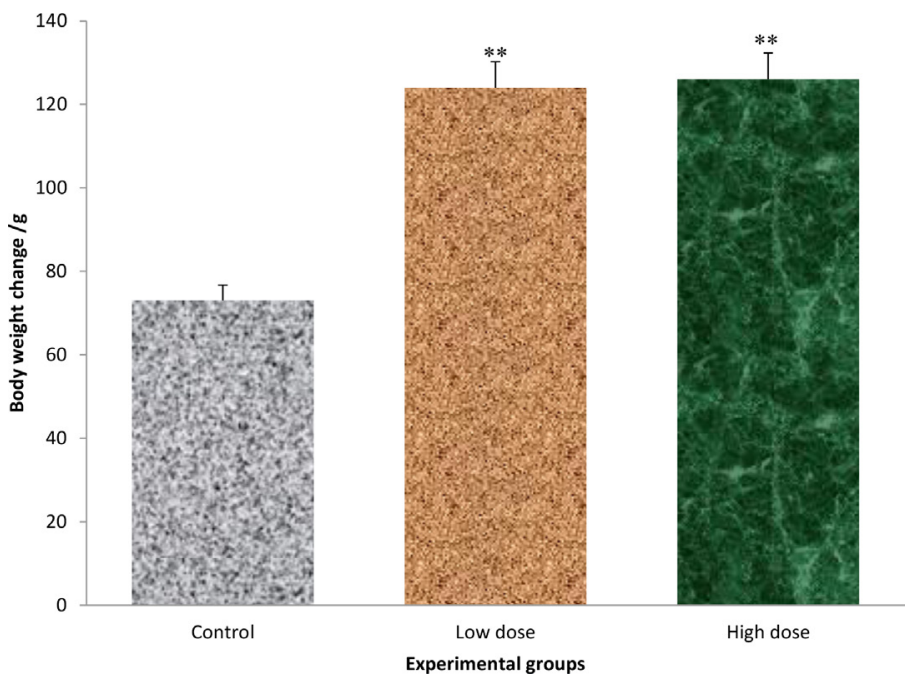

Figure 6: Comparison of the body weight change between the control and Nymphaea lotus treated groups. Values are mean $\pm \mathrm{SEM}, n=10 .{ }^{* *} P<0.01$ vs. control.

group administered Nymphaea lotus showed significantly higher body weight change compared to control $(P<0.01)$.

\section{DISCUSSION}

The open field maze and light-dark box is designed to test unconditioned anxiety and exploratory behaviors. It is based on the conflict between exploring a novel environment and avoidance of bright light. ${ }^{[7]}$ Behaviors such as the number of line crosses and frequency of rearing are used as measures of exploration. ${ }^{[8]} \mathrm{A}$ higher frequency of these measures (line crosses, rearing) indicates increased exploratory and locomotor behavior. It was observed that the frequency of line crosses in the group of mice treated with Nymphaea lotus was significantly higher compared to the control. This indicates an increased exploratory activity. This means that increase exploratory behavior in the mice may be probably due to unknown constituents in the leave of the plant (Nymphaea lotus) which may have a stimulatory effect on the nervous system, such as on the cerebellum, motor cortex or spinal cord. ${ }^{[9,10]}$ The frequency of transition was significantly increased in the treated mice when compared to the control. This means that the animals spent more time exploring the surroundings, which implies that the test animals were less fearful. Behaviors such as frequency of Stretch Attend Posture (SAP) and frequency grooming in the open field was observed to be lower in the Nymphaea lotus treated group compared to control. This means that the animals were less hesitant in moving from one place to another. It is a behavior exhibited by rodents introduced in a novel environment and it is a measure of exploratory behavior. ${ }^{[11]}$ This also indicates an increase in exploratory behavior in the test group compared to the control.

The mean body weight was observed to be significantly higher in the mice administered with the leaves of Nymphaea lotus compared to control. This could be due to the high food and water intake recorded $n$ the study. This result is consistent with earlier studies carried out by. ${ }^{[12]}$

\section{CONCLUSION}

Chronic exposure of powdered tobacco diet in mice improves exploratory behavior and increase body weight change. 


\section{ACKNOWLEDGEMENT}

The authors wish to acknowledge the assistance of Mr. Joshua Iwasam in collection of the sample and who helped in the laboratory.

\section{ABBREVIATIONS}

SAP: Stretch Attend Posture.

\section{REFERENCES}

3. Akinjogunla OJ, Adegoke AA, Udokang IP, Adebayo-Tayo BC. Microbial potential of Nymphaea lotus (Nymphaeaceae) against wound pathogens. J Med Plants Res. 2009;3(3):138-41.

4. Carlini EA. Plants and the central nervous system. Pharmacology Biochemistry and Behavior. 2003;75(3):501-12.

5. Abu-Zaida ME, Mashaly IA, AbdEI-Monem M, Torky M. Economic potentials of some aquatic plants growing in North East Nile delta, Egypt. J Applied Sci. 2008;8(1):1395-405

6. Madhusudhanan N, Lakshmi T, Kumar SG, Venu G. In vitro antioxidant and free radical scavenging activity of aqueous and ethanolic flower extract of
Nymphaea alba. Int J Drug Dev Res. 2011;3(3):252-8.

7. Mohammed HA, Uka UN, Yauri YAB. Evaluation of nutritional composition of water lily (Nymphaea lotus) from Tatabu flood plain, North-central Nigeria. Journal of Fisheries and Aquatic Science Neurosci Biobehav Rev. 2012;9:37-44.

8. Afolayan AJ, Sharaibi OJ, Kazeem MI. Phytochemical analysis and in vitro antioxidant activity of Nymphaea lotus. International Journal of Pharmacology 2013;9(5):297-304

9. Bourin M, Hascoet M. The mouse light / dark box. European Journal of Pharmacology. 2003;463(1-3):55-65

10. Walsh RN, Cummins RA. The open field test, a critical review. Psychological Bulletin. 1976;83(3):482-504

11. Brown RE, Corey SC, Moore AK. Differences in measures of exploration and fear in $\mathrm{MHC}$-congenic $\mathrm{C} 57 \mathrm{BL} / 6 \mathrm{~J}$ and $\mathrm{B} 6-\mathrm{H}-2 \mathrm{~K}$ mice. Behavior Genetics. 2004;29:263-71.

12. Mesembe O, Bisong S, Ekong M, Ekeoma A. Neurobehavioral activity in Albino wistar Rats in the open field maze following long term Tobacco Diet ingestion. The Internet Journal of Neurology. 2008;10(2):1-6.

13. Nilson R. A qualitative and quantitative risk assessment of snuff dipping. Regulatory Toxicology and Pharmacology. 1998;28(1):1-16.

14. Aduema W, Warso AC, Agbai JU, Amah AK. Effects of ethanolic extract of Nymphaea lotus leave (water lily) on locomotor behavior in Swiss mice. World Journal of Medical Science. 2017;14(4):135-40.

Cite this article: Wadioni A, Vidona WB, Chris A, Kalu AA. Acute Administration of Nymphaea lotus Increases Body Weight and Exploratory Behaviour in Mice. Int J Clin Exp Physiol. 2019;6(3):82-5. 